\title{
Does partial preservation of residual beta-cell function justify immune intervention in recent onset Type I diabetes?
}

\author{
H.Kolb ${ }^{1}$, E.A.M. Gale ${ }^{2}$ \\ ${ }^{1}$ German Diabetes Research Institute at the University of Düsseldorf, Germany \\ ${ }^{2}$ Diabetes and Metabolism, Division of Medicine, University of Bristol, UK
}

\section{Abstract}

Immune intervention seems to offer the prospect of preventing or reversing the hyperglycaemic phase of Type I (insulin-dependent) diabetes mellitus. A number of prevention trials have been undertaken before disease onset but the logistics of such trials are prohibitive. More rapid and less expensive means of testing new therapies are needed and the current emphasis is therefore on intervention after diagnosis to salvage residual beta-cell function. At present, because restoration of normal metabolism seems unattainable, such interventions are tested against their ability to maintain C-peptide production over the first months or years of diabetes.

C-peptide provides a useful surrogate measure of response with which to identify therapies that might justify more exhaustive investigation at an earlier stage of the disease process. As immune intervention is potentially harmful, the risks and benefits of participation in such trials require careful consideration. Therefore what is the evidence that preservation of residual insulin secretion provides clinical benefit to the patient? Trials capable of proving a direct causal link are lacking and might not be feasible. There is, however, a wealth of indirect evidence which requires careful scrutiny and debate, since this provides the basis for current attempts at immunotherapy. [Diabetologia (2001) 44: 1349-1353]

Keywords Type I diabetes, C-peptide, metabolic control, diabetic complications, immune intervention in Type I diabetes, remission, partial remission, residual beta-cell function, hypoglycaemia, islet transplantation.

\section{Background}

Most patients with Type I diabetes can secrete useful amounts of endogenous insulin in response to stimulation tests for a period after diagnosis $[1,2,3]$. Postmortem studies indicate that the insulin content of the pancreas is reduced to about $10 \%$ in young patients [4] and histological sections taken soon after disease onset show that some 5 to $20 \%$ of islet cells stain for insulin [5]. Many of these patients, however, died in hyperglycaemic crisis, and otherwise functional beta cells could have been depleted of insulin. Animal studies suggest that at diagnosis beta-cells are

Corresponding author: H. Kolb, German Diabetes Research Institute, Auf'm Hennekamp 65, 40225 Düsseldorf, Germany, e-mail: kolb@dfi.uni-duesseldorf.de present which do not stain for insulin and that these can function effectively in a non-inflammatory environment $[6,7]$. Equally, human studies show that residual beta-cell function often improves over the first months of insulin treatment, as judged by C-peptide production after stimulation with glucagon or a test meal, but fades away gradually over time $[3,8,9]$.

The first immune intervention trials in recent onset Type I diabetes aimed for full remission, i. e. independence from insulin $[10,11]$, but this goal so far has not been reached $[9,12,13]$. A number of well controlled trials have, however, reported preservation of residual insulin secretion over 12 to 18 months or more $[9,11,14,15,16,17,18,19,20]$. It is thus clear that immune intervention backed by insulin replacement therapy can delay the loss of beta-cell function in Type I diabetes. In contrast, there is also evidence 
that insulin therapy alone can delay the loss of residual C-peptide secretion $[8,21]$, though intensified insulin therapy did not prolong this effect for more than 3 to 6 years after diagnosis. [3].

The risks and possible benefits of immunotherapy in the prevention or treatment of Type I diabetes in children have been critically discussed $[22,23]$ and are readdressed here. Our aim is to discuss whether preservation of residual beta-cell function after diagnosis of Type I diabetes is of sufficient benefit to the patient to justify adjunct immunotherapy or other interventions such as gene therapy, enhancement of beta-cell regeneration or stem cell transplantation.

\section{Preserving beta-cell function: is there direct evidence of benefit?}

Direct proof would require a controlled trial to show that maintained endogenous insulin secretion benefits disease morbidity and quality of life, yet no such trial has been undertaken. A trial of this sort would require randomisation of matched patient groups with identical C-peptide production followed by intervention to preserve endogenous insulin secretion in one group. The study should be blinded to ensure that other aspects of care such as insulin treatment are offered impartially. The experimental treatment should not affect morbidity and mortality, and such effects might be difficult to identify and exclude with immune intervention. Finally, the trial should last for a minimum of 5 years to have a sufficiently high incidence of outcomes, as in the Diabetes Control and Complications Trial (DCCT) [3, 24]. These considerations and the current lack of safe and effective intervention, make it unlikely that direct evidence of the benefit of preserving beta-cell function will become available in the near future.

\section{Residual C-peptide secretion versus metabolic control}

Cross-sectional studies in long term Type I diabetes show that patients with residual C-peptide secretion have better metabolic control as determined by $\mathrm{HbA}_{1 \mathrm{c}}$ concentrations [25, 26, 27, 28]. This observation should be interpreted with care, since skilled insulin therapy would be expected to promote survival of beta cells by reducing metabolic demand and glucose toxicity, and residual endogenous insulin secretion might therefore be a consequence rather than a cause of good metabolic control. Conversely, high glucose concentrations have been shown to damage beta-cell function in vitro or in vivo [29, 30], and in the DCCT beta-cell function (stimulated C-peptide concentrations $\geq 0.2 \mathrm{pmol} / \mathrm{ml}$ ) was higher in the intensive insulin treatment group (median $\mathrm{HbA}_{1 \mathrm{c}}$ concentrations around $7 \%$ ) than in the conventional in- sulin treatment group (median $\mathrm{HbA}_{1 \mathrm{c}}$ concentrations around 9\% ) [3]. Metabolic control and endogenous insulin secretion are therefore not independent of one another and causes and consequences of preserved beta-cell function could therefore be difficult to disentangle.

Patients with residual C-peptide secretion require less insulin, and those who need doses of less than $0.1-0.2$ units $/ \mathrm{kg}$ body weight to maintain good metabolic control have near normal blood glucose profiles with little early morning increase in fasting blood glucose concentrations [31,32]. An additional benefit of stable glucose control is that it is not aggravated by counterregulatory hormones released in response to changing glucose concentrations, explaining the old clinical saying that "good control begets good control". There can therefore be little dispute that wellpreserved endogenous insulin secretion curbs transient hyperglycaemia, with resulting improvement in $\mathrm{HbA}_{1 \mathrm{c}}$ and risk of long term complications.

This effect was confirmed in the DCCT, in which the intensively treated group could be subdivided according to residual C-peptide secretion at entry to the trial. The sub-group with the highest stimulated C-peptide had significantly $(p<0.01)$ lower $\mathrm{HbA}_{1 \mathrm{c}}$ over the first four years of the study and $50 \%$ less risk of progression of retinopathy, with a similar trend for microalbuminuria [3]. Patients with higher C-peptide responses at diagnosis might arguably have a less aggressive form of the disease with lower risk of chronic complications, but DCCT showed that those with a good initial C-peptide response are not protected from diabetic complications under conditions of suboptimal metabolic control and rapidly lose residual beta-cell function [3].

\section{Residual beta-cell function and hypoglycaemia}

Hypoglycaemia is the major limiting factor for improved metabolic control in Type I diabetes [33] and greatly reduces the motivation of patients to comply with intensive insulin treatment regimens. A minority of patients have been so disabled by recurrent hypoglycaemia as to justify pancreas or islet transplantation. Islet transplantation has until recently resulted in transient subnormal restoration of beta-cell function rather than normoglycaemia [34], and therefore provides a useful model of partial beta-cell function. Several trials have reported major improvement in symptoms of hypoglycaemia within weeks of transplantation. Adrenaline, noradrenaline and cortisol responses to hypoglycaemia increased markedly, although the glucagon response was not restored and all patients regained autonomic warning symptoms $[35,36,37]$. Because hypoglycaemia does not improve after kidney transplantation, these benefits are not due to immunosuppression. These studies 
therefore prove a causal link between residual betacell function and reduced risk of hypoglycaemia. Comparable benefits were seen in the DCCT, in which patients on intensified treatment with baseline stimulated C-peptide responses $\geq 0.2 \mathrm{pmol} / \mathrm{ml}$ had $65 \%$ less risk $(95 \%$ confidence interval $53 \%$ to $74 \%$ ) for severe hypoglycaemia with seizure or coma despite significantly lower concentrations of $\mathrm{HbA}_{1 \mathrm{c}}[3]$.

\section{Other potential benefits of residual beta-cell function}

Partial restoration of endogenous insulin secretion has been reported to normalise protein and lipid metabolism [38]. It should also be noted that beta cells do more than secrete insulin. C-peptide might itself have a physiological role, and specific saturable high affinity binding to a putative receptor has been reported for several human cell types [39]. Short-term intervention studies with exogenous C-peptide report improved renal function in diabetic nephropathy and improved nerve function in diabetic neuropathy. Improvement within the microcirculation was also reported in association with improved erythrocyte deformability and increased activity of endothelial nitric oxide synthase and erythrocyte $\mathrm{Na}^{+}, \mathrm{K}^{+}$-ATPase [40, 41, 42, 43, 44, 45].

Another beta-cell product is amylin, a peptide which acts centrally to modulate gastrointestinal function [46, 47]. The amylin analogue pramlintide acts synergistically with insulin to improve glucose control in Type I diabetes [48]. In addition, functional beta-cells form an important element in the community of cells in the pancreatic islets, are electrically coupled to other islet cell types through gap junctions and could have other useful actions including trophic effects on pancreatic exocrine tissue $[49,50]$. Preservation of functional beta cells therefore offers a range of other potential benefits, although at present it is not possible to establish how important these might be.

\section{Conclusions}

Definitive proof that the preservation of beta-cell function is beneficial must await prospective studies and these will only be feasible when acceptably safe and successful immune intervention becomes available. In the interim, there is compelling evidence that residual beta-cell function is associated with improved metabolic control, with reciprocal benefits for residual beta-cell function, and reduced risk of severe hypoglycaemia. As yet there is no formal proof that long term maintenance of C-peptide responses will decrease morbidity and mortality but the indirect evidence makes this a justifiable inference.
One current limitation is that we do not know what constitutes a "protective" residual C-peptide response. Although threshold concentrations are widely used to define such responses, the benefits of residual insulin production are likely to be dose-dependent and even minimal improvement should in theory produce some clinical benefit. Very large prospective studies would be needed to clarify this point and these would be hard to justify at present. Meanwhile we lack vital information about the key end-point used for intervention studies in newly diagnosed patients. Are threshold concentrations of C-peptide adequate or should we compare differences between groups in terms of mean responses to stimulation, and should such differences be assessed in absolute or relative terms? At present, these questions cannot be answered. Equally, it is not possible to separate the benefits of preserved endogenous beta-cell function from those of improved glycaemic control. Both are desirable and both are synergistic. Immune intervention trials imply that insulin treatment should be optimised. Subjective factors play a major part in metabolic control and such trials should therefore be blinded whenever possible.

Despite current limitations in knowledge, we conclude that partial preservation of residual beta-cell function after diagnosis is an important goal of therapy and that intervention trials aimed at preservation of C-peptide secretion deserve careful consideration. The possibility of direct clinical benefit to participants in such studies should be weighed carefully against the safety profile and potential hazards of each form of intervention. After all, and despite the high risk of disabling late complications, insulin therapy does offer such patients decades of life. We therefore emphasise that safety remains of paramount concern in planning clinical trials in newly diagnosed patients. A further potential benefit of immune intervention in newly diagnosed patients is that it can be used to establish proof of principle for interventions which might subsequently be taken into the prediabetic phase of the disease. At present trials in newly diagnosed patients offer the most ethical and cost-effective means of obtaining such evidence.

Acknowledgements. This paper was supported by the Bundesminister für Gesundheit, the Minister für Wissenschaft und Forschung des Landes Nordrhein-Westfalen.

\section{References}

1. Madsbad S, Krarup T, Regeur L, Faber OK, Binder C (1981) Effect of strict blood glucose control on residual beta-cell function in insulin-dependent diabetics. Diabetologia 20: 530-534

2. Perlman K, Ehrlich RM, Filler RM, Albisser AM (1984) Sustained normoglycemia in newly diagnosed type 1 diabetic subjects. Diabetes 33: 995-1001 
3. The Diabetes Control and Complications Trial Research Group (1998) Effect of intensive therapy on residual b-cell function patients with type 1 diabetes in the diabetes control a complications trial. A randomized, controlled trial. Ann Intern Med 128: 517-523

4. Wrenshall GA, Bogoch A, Ritchie R (1951) Extractable insulin of pancreas. Diabetes 1: 87-107

5. Gepts W, Lecompte PM (1981) The panreatic islets in diabetes. Am J Med 70: 105-115

6. Eizirik DL (1996) Beta-cell defence and repair mechanisms in human pancreatic islets. Horm Metab Res 28: 302-305

7. Chatenoud L, Primo J, Bach JF (1997) CD3 antibody-induced dominant self tolerance in overtly diabetic NOD mice. J Immunol 158: 2947-2954

8. The DCCT Research Group (1987) Effects of age, duration and treatment of insulin-dependent diabetes mellitus on residual beta-cell function: observation during eligbility testing for the Diabetes Control and Complications Trial (DCCT). J Clin Endocrinol Metab 65: 30-36

9. Martin S, Schernthaner G, Nerup J (1991) Follow-up of cyclosporin A in Type I (insulin dependent) diabetes mellitus: lack of long term effects. Diabetologia 34: 429-434

10. Feutren G, Papoz L, Assan R et al. (1986) Cyclosporin increases the rate and length of remissions in insulin-dependent diabetes of recent onset. Lancet ii: 119-123

11. Canadian European Diabetes Study Group (1988) Cyclosporin-induced remission of IDDM after early intervention. Association of $1 \mathrm{yr}$ of cyclosporin treatment with enhanced insulin secretion. Diabetes 37: 1574-1582

12. Pozzili P (1998) Prevention of insulin-dependent diabetes mellitus 1998. Diabetes Metab Rev 14: 69-84

13. Becker DJ, LaPorte RE, Libman I, Pietropaolo M, Dosch H-M (2000) Prevention of type 1 diabetes: Is now the time? J Clin Endocrinol Metab 85: 498-506

14. Pozzilli P., Browne PD, Kolb H, The Nicotinamide Trialists (1996) Meta-analysis of nicotinamide treatment in patients with recent-onset IDDM. Diabetes Care 19: 1357-1363

15. MacDonald MJ, Shahidi NT, Allen DB, Lustig RH, Mitchell TL, Cornwell ST (1994) Pentoxifylline in the treatment of children with new-onset type 1 diabetes mellitus. JAMA 271: 27-28

16. Björk E, Berne C, Kämpe O, Wibell L, Oskarsson P, Karlsson FA (1996) Diazoxide treatment at onset preserves residual insulin secretion in adults with autoimmune diabetes. Diabetes 45: 1427-1430

17. Montanya E, Fernandez-Castaner M, Soler J (1997) Improved metabolic control preserved beta-cell function two years after diagnosis of insulin-dependent diabetes mellitus. Diabetes Metab 23: 314-319

18. Schnell O, Eisfelder B, Standl E, Ziegler A-G (1997) Highdose intravenous insulin infustion versus intensive insulin treatment in newly diagnosed IDDM. Diabetes 46: $1607-1611$

19. Coutant R, Landais P, Rosilio M et al. (1998) Low dose linomide in Type I juvenile diabetes of recent onset: a randomised placebo-controlled double blind trial. Diabetologia 41: 1040-1046

20. Elias D, Metzger M, Avron A et al. (2001) C-peptide preservation and Th1 to Th2 shift in type 1 diabetes patients vaccinated with DiaPep277. Diabetes Metab Rev 17: S39

21. Shah SC, Malone JI, Simpson RN (1989) A randomized trial of intensive insulin therapy in newly diagnosed insulindependent diabetes mellitus. N Engl J Med 320: 550-554

22. Rosenbloom AL, Schatz DA, Krischer JP, et al. (2000) Therapeutic controversy: Prevention and treatment of diabetes in children. J Clin Endocrinol Metab 85: 494-522
23. Drash AL (1995) Is it time to draw the curtain on immune intervention trials in newly diagnosed patients with iddm? Diabetes Care 18: 1499-1501

24. The DCCT Research Group (1993) The effect of intensive treatment of diabetes on the development and progression of long-term complications in insulin-dependent diabetes mellitus. New Engl J Med 329: 977-986

25. Sjöberg S, Gunnarsson R, Gjötterberg M, Lefvert AK, Persson A, Östman J (1987) Residual insulin production, glycaemic control and prevalence of microvascular lesions and polyneuropathy in long-term Type I (insulin-dependent) diabetes mellitus. Diabetologia 30: 208-213

26. Winocour PH, Jeacock J, Kalsi P, Gordon C, Anderson DC (1990) The relevance of persistent C-peptide secretion in type 1 (insulin-dependent) diabetes mellitus to glycaemic control and diabetic complications. Diabetes Res Clin Pract 9: 23-35

27. Nakanishi K, Kobayashi T, Inoko H, Tsuji K, Murase T, Kosaka K (1995) Residual b-cell function and HLA-A24 in IDDM. Diabetes 44: 1334-1339

28. Herbini G, Mangili R, Luzi L (1999) Higher post-absorptive C-peptide levels in type 1 diabetic patients without renal complications. Diabet Med 16: 1048

29. Weir GC, Laybutt DR, Kaneto H, Bonner-Weir S, Sharma A (2001) Beta-cell adaptation and decompensation during the progression of diabetes. Diabetes 50 [Suppl. 1]: S154S159

30. Roche E, Maestre I, Martin F et al. (2000) Nutrient toxicity in pancreatic beta-cell dysfunction. J Physiol Biochem 56: 119-128

31. Werther GA, Turner RC, Jenkins PA, Baum JD (1982) Twenty-four hour profiles of plasma C-peptide in Type I (insulin-dependent) diabetic children. Diabetologia 22: 245-249

32. Fukuda M, Tanaka A, Tahara Y et al. (1988) Correlation between minimal secretory capacity of pancreatic b-cells and stability of diabetic control. Diabetes 37: 81-88

33. Cryer PE (1994) Hypoglycemia: the limiting factor in the management of IDDM. Diabetes 43: 1378-1389

34. Kenyon NS, Ranuncoli A, Masetti M, Schatzipetrou M, Ricordi C (1998) Islet transplantation: Present and future perspectives. Diabetes Metab Rev 14: 303-313

35. Kendall DM, Rooney DP, Smets YF, Salazar BL, Robertson RP (1997) Pancreas transplantation restores epinephrine response and symptom recognition during hypoglycemia in patients with long-standing type 1 diabetes and autonomic neuropathy. Diabetes 46: 249-257

36. Meyer C, Hering BJ, Großmann R et al. (1998) Improved glucose counterregulation and autonomic symptoms after intraportal islet transplants alone in patients with longstanding type 1 diabetes mellitus. Transplantation 66: 233-240

37. Federlin K, Pozza G (1999) Indications for clinical islet transplantation today and in the foreseeable future - The diabetologist point of view. J Mol Med 77: 148-152

38. Luzi L, Perseghin G, Brendel MD et al. (2001) Metabolic effects of restoring partial b-cell function after islet allotransplantation in type 1 diabetic patients. Diabetes 50: 277-282

39. Rigler R, Pramanik A, Jonasson P et al. (1999) Specific binding of proinsulin C-peptide to human cell membranes. Proc Natl Acad Sci USA 96: 13318-13323

40. Johansson BL, Borg K, Fernqvist-Forbes E, Odergren T, Remahl S, Wahren J (1996) C-peptide improves autonomic nerve function in IDDM patients. Diabetologia 39: 687-695 
41. Forst T, Kunt T, Pohlmann T et al. (1998) Biological activity of C-peptide on the skin microcirulation in patients with insulin-dependent diabetes mellitus. J Clin Invest 101: 2036-2041

42. Kunt T, Schneider S, Pfutzner A et al. (1999) The effect of human proinsulin C-peptide on erythrocyte deformability in patients with type 1 diabetes mellitus. Diabetologia 42: 465-471

43. Johansson B-L, Borg K, Fernqvist-Forbes E, Kernell A, Odergren T, Wahren J (2000) Beneficial effects of C-peptide on icipient nephropathy and neuropathy in patients with type 1 diabetes mellitus. Diabet Med 17: 181-189

44. Forst T, De La Tour DD, Kunt T et al. (2000) Effects of proinsulin $\mathrm{C}$-peptide on nitric oxide, microvascular blood flow and erythrocyte $\mathrm{Na}^{+} \mathrm{K}^{+}$-ATPase activity in diabetes mellitus type 1. Clin Sci (Colch) 98: 283-290

45. Wahren J, Ekberg K, Johansson J et al. (2000) Role of Cpeptide in human physiology. Am J Physiol Endocrinol Metab 278: E759-E768
46. Jorgensen JO, Rosenfalck AM, Fisker S et al. (2000) Circulating levels of incretin hormones and amylin in the fasting state and after oral glucose in GH-deficient patients before and after GH replacement: a placebo-controlled study. Eur J Endocrinol 143: 593-599

47. Gebre-Medhin S, Olofsson C, Mulder H (2000) Islet amyloid polypeptide in the islets of Langerhans: friend or foe? Diabetologia 43: 687-695

48. Gale EAM, Clark A (2000) A drug on the market. Lancet 355: 61-63

49. Mears D, Sheppard NF jr, Atwater I, Rojas E (1995) Magnitude and modulation of pancreatic beta-cell gap junction electrical conductance in situ. J Memb Biol 146: 163-176

50. Hardt PD, Krauss A, Bretz L et al. (2000) Pancreatic exocrine function in patients with type 1 and type 2 diabetes mellitus. Acta Diabetol 37: 105-110 